\title{
Thermal Analysis of Steam Turbine Power Plants
}

\author{
Ivan Sunit Rout ${ }^{1}$, Abhishek Gaikwad ${ }^{1}$, Vinod Kumar Verma ${ }^{1}$, \\ Mohammad Tariq ${ }^{1}$ \\ ${ }^{1}$ (Assistant Professor, Department of Mechanical Engineering, Sam Higginbottom Institute of Agriculture, \\ Technology and Sciences, Allahabad, India)
}

\begin{abstract}
Steam are a major energy consumer. Optimising process operating conditions can considerably improve turbine water rate, which in turn will significantly reduce energy requirement. Various operating parameters affect condensing and back pressure turbine steam consumption and efficiency. The industrial sector is the largest energy consumer, accounting for about $30 \%$ of total energy used. Fuel and energy prices are continuously rising. With the present trend of energy prices and scarcity of hydrocarbon resources lowering energy requirement is a top priority. Energy conservation benefits depend on the adopting minor or major modifications and using the latest technology. Turbines are designed for a particular operating conditions like steam inlet pressure, steam inlet temperature and turbine exhaust pressurel exhaust vacuum, which affects the performance of the turbines in a significant way. Variations in these parameters affects the steam consumption in the turbines and also the turbine efficiency. The present study was done to improve the power output of the turbine, thermal efficiency and specific steam consumption in conventional steam power plants. Three cycles i.e regenerative cycle, superheater cycle and cogeneration cycle are considered to formulate the data and obtain a better result in steam turbine power plants.
\end{abstract}

Keywords: Cogeneration Cycle, Rankine Cycle, Regenerative Cycle, Superheater Cycle, Turbine inlet temperature

\section{INTRODUCTION}

Power plants are where power is produced such as in the electricity generating stations and jet engines. The workings of these power plants are based on the turbine used. Steam has been a popular mode of conveying energy since the industrial revolution. Steam is used for generating power and also used in process industries such as sugar, paper, fertilizer, refineries, petrochemicals, chemical, food, synthetic fibre and textiles. The following characteristics of steam make it so popular and useful to the industry:

- Highest specific heat and latent heat

- Highest heat transfer coefficient

- Easy to control and distribute

- Cheap and inert

\subsection{Rankine Cycle}

The steam turbine power plant is based on the rankine cycle which consists of five processes: two isothermals, two isentropics and one constant pressure.

Process 1-2: This shows the isentropic expansion of steam in the turbine from pressure $\mathrm{p}_{1}$ to $\mathrm{p}_{2}$.

Process 2-3: At constant pressure $\mathrm{p}_{2}$ and temperature $\mathrm{T}_{2}$, the exhaust steam from the steam turbine is condensed in the condenser.

Process 3-4: The water from the hot-well or the surge tank which is at low pressure is pumped into the boiler at high pressure $p_{1}$. Here pumping process 3-4 is isentropic.

Process 4-5: As the water enters the boiler, water is first heated up to the saturation temperature or evaporation temperature $T_{1}$ called sensible heating and during this process the state point moves along curve $4-5$. The heat supplied during this process is $\mathrm{h}_{\mathrm{f5}}-\mathrm{h}_{\mathrm{f4}}$ and is called sensible heat of water.

Process 5-1: At constant pressure $\mathrm{p}_{1}$ and temperature $T_{1}$, water is completely evaporated into steam. The heat supplied in this process is equal to $\mathrm{h}_{1}-\mathrm{h}_{\mathrm{f5}}$ and is called latent heat of vaporization. 


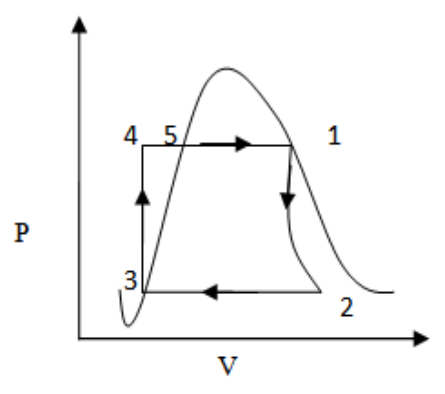

Figure 1: P-V diagram of rankine cycle

\subsection{Regenerative Cycle}

In this cycle, the feed water is preheated by means of steam taken from some sections of the turbine, before it enters the boilers from the condenser. This process of draining steam from the turbine at certain point during its expansion and using this steam for heating the feed water supplied to the boiler is known as "Bleeding." The effect of this process is to supply the boiler with hotter water while a small amount of work is lost by the turbine.

Process 1-2: The steam is bled from the turbine and passed on to the heater.

Process 1-3: This shows the isentropic expansion of remaining steam in the turbine from pressure $p_{1}$ to $p_{3}$.

Process 3-4: At constant pressure $p_{3}$ and temperature $T_{3}$, the exhaust steam from the steam turbine is condensed in the condenser.

Process 4-5: Here the feed water from condenser is pumped to heater.

Process 5-6: In this heater $\left(1-\mathrm{m}_{\mathrm{s}}\right) \mathrm{kg}$ of steam is heated.

Process 2-6: In this heater $\mathrm{m}_{\mathrm{s}} \mathrm{kg}$ of steam condenses.

Process 6-7: The water from the heater which is at low pressure is pumped into the boiler at high pressure.

Process 7-1: At constant pressure $\mathrm{p}_{1}$ and temperature $\mathrm{T}_{1}$, water is completely evaporated into steam.

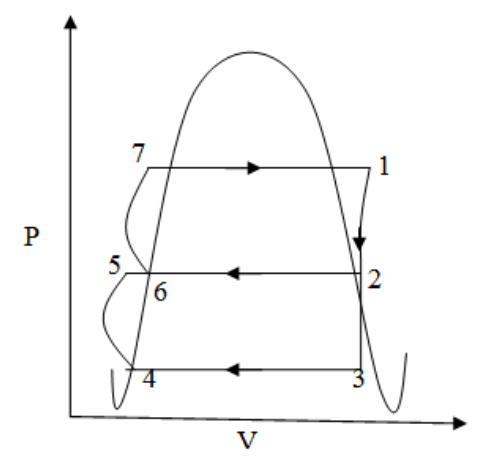

Figure 2: P-V diagram of regenerative cycle

\subsection{Superheater Cycle}

A superheater is a device that heats the steam generated by the boiler again, increasing its thermal energy and decreasing the likelihood that it will condense inside the engine. Superheaters increase the efficiency of the steam turbine, and were widely adopted. Steam which has been superheated is logically known as superheated steam. Superheated steam is steam at a temperature higher than boiling point of water. If saturated steam is heated at constant pressure, its temperature will also remain constant as the steam quality (think dryness) increases towards $100 \%$ dry saturated steam. Continued heat input will then generate superheated steam. 


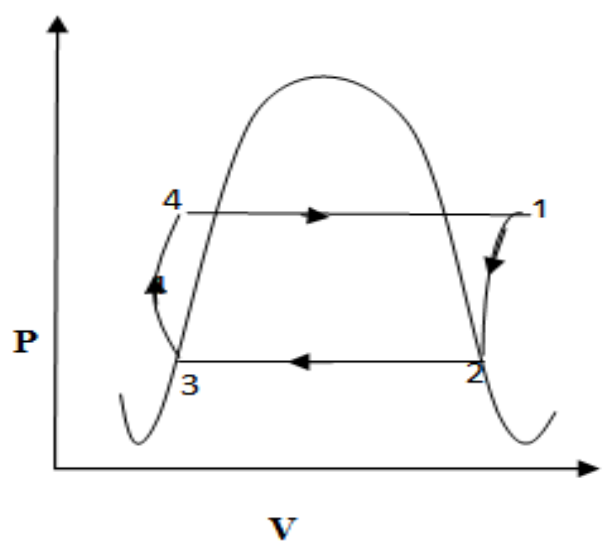

Figure 3: P-V diagram of superheater cycle

\subsection{Cogeneration Cycle}

Cogeneration or Combined Heat and Power (CHP) is defined as the sequential generation of two different forms of useful energy from a single primary energy source, typically mechanical energy and thermal energy. Mechanical energy may be used either to drive an alternator for producing electricity, or rotating equipment such as motor, compressor, pump or fan for delivering various services. Thermal energy can be used either for direct process applications or for indirectly producing steam, hot water, hot air for dryer or chilled water for process cooling. Cogeneration provides a wide range of technologies for application in various domains of economic activities. The overall efficiency of energy use in cogeneration mode can be up to 85 per cent and above in some cases.

Process 1-2: The steam is continuously extracted from the turbine and passed on to the process heater.

Process 1-3: This shows the isentropic expansion of remaining steam in the turbine from pressure $p_{1}$ to $p_{3}$.

Process 3-4: At constant pressure $p_{3}$ and temperature $T_{3}$, the exhaust steam from the steam turbine is condensed in the condenser.

Process 4-5: The water from the hot-well or the surge tank which is at low pressure is pumped into the boiler at high pressure . Here pumping process $4-5$ is isentropic.

Process 2-6: The steam which could have been a waste is utilized as a process heat to generate electricity.

Process 6-7: The water from the process heater which is at low pressure is pumped into the boiler at high pressure.

Process 8-1: Here water is completely evaporated into steam and this steam enters the turbine.

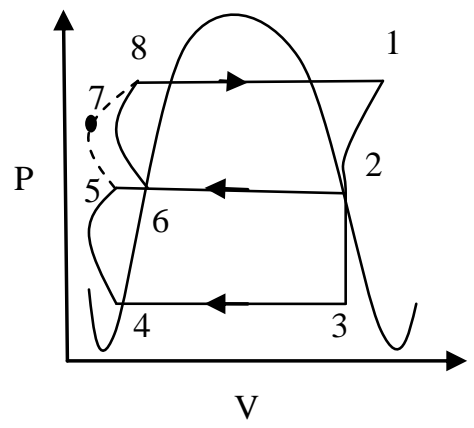

Figure 4: P-V diagram of cogeneration cycle

\section{ANALYSIS}

At $P_{1}$ bar, the value of entrance enthalpy $h_{1} \mathrm{~kJ} / \mathrm{kg}$ is taken.

From Steam table, At $\mathrm{P}_{2}=0.1 \mathrm{bar} ; \mathrm{h}_{\mathrm{f} 2}=191.8 \mathrm{KJ} / \mathrm{Kg}$ and $\mathrm{h}_{\mathrm{fg} 2}=2392.8 \mathrm{~kJ} / \mathrm{kg}$ is found out.

Given: dryness fraction of steam, $\mathrm{x}_{2}=0.9$

Exit enthalpy from turbine $\mathrm{h}_{2}=\mathrm{h}_{\mathrm{f} 2}+\mathrm{x}_{2} \times \mathrm{h}_{\mathrm{fg} 2} \quad(\mathrm{~kJ} / \mathrm{kg})$

Energy balance on condenser,

Heat lost by steam $=$ heat gained by cooling water

$\mathrm{Q}_{2}=\mathrm{C}_{\mathrm{p}}\left(\mathrm{T}_{2}-\mathrm{T}_{1}\right) \times \mathrm{m}_{\mathrm{w}}(\mathrm{kJ} / \mathrm{h})$

From steam table, At $\mathrm{P}_{3}=0.09$ bar; $\mathrm{h}_{\mathrm{f} 3}=183.3(\mathrm{~kJ} / \mathrm{kg})$ 
The mass flow rate of steam, $\mathrm{m}_{\mathrm{s}}=\frac{\mathrm{Q}_{2}}{\mathrm{~h}_{2}-\mathrm{h}_{\mathrm{f} 3}}(\mathrm{~kg} / \mathrm{h})$

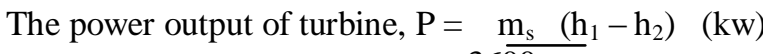

$$
36 \widehat{00}
$$

The thermal efficiency of the plant, $\eta_{\mathrm{s}}=\mathrm{h}_{1}-\mathrm{h}_{2}$

$$
\mathrm{h}_{1}-\mathrm{h}_{\mathrm{f} 2}
$$

The work done on the turbine, $\mathrm{W}_{\mathrm{T}}=\mathrm{h}_{1}-\mathrm{h}_{2}(\mathrm{~kJ} / \mathrm{kg})$

The work done on the pump, $\mathrm{W}_{\mathrm{p}}=\mathrm{V}_{\mathrm{f}(\mathrm{p} 2)} \times\left(\mathrm{P}_{1}-\mathrm{P}_{2}\right) \times 100$

The net work done, $\mathrm{W}_{\text {net }}=\mathrm{W}_{\mathrm{T}}-\mathrm{W}_{\mathrm{p}}(\mathrm{kJ} / \mathrm{kg})$

Specific Steam Consumption, $\mathrm{SSC}=\underline{3600} \quad(\mathrm{~kg} / \mathrm{kWh})$

$$
\mathrm{W}_{\text {net }}
$$

\section{Results and discussion}

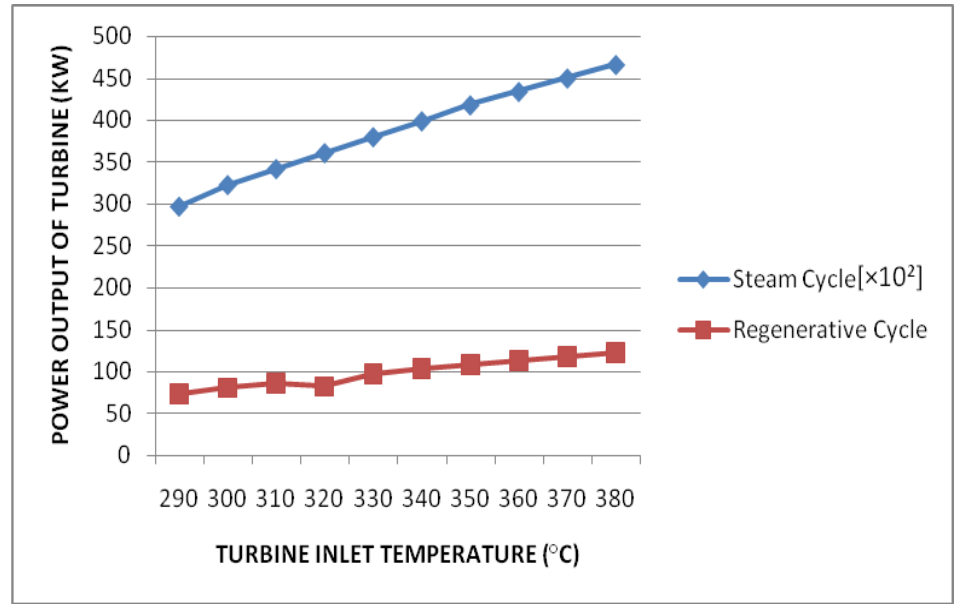

figure 5: Power output vs TIT

This Fig 5 shows the variation of the power output of the turbine with turbine inlet temperature. The increase in turbine inlet temperature means an increase in superheat at constant inlet steam pressure and condenser pressure gives a steady improvement in the power output of the turbine. Raising the inlet steam temperature also reduces the wetness of the steam in the later stages of the turbine and improves the power output of the turbine. In steam cycle, the power output of the turbine increases uniformly with increase in turbine inlet steam temperature which thereby increases the quality of steam at the turbine exhaust. However, in regenerative cycle the power output of the turbine increases steadily with increase in turbine inlet temperature and is lower than simple steam cycle as some of the steam is bled from the turbine and brought back through the heater and fed to the boiler through pump.

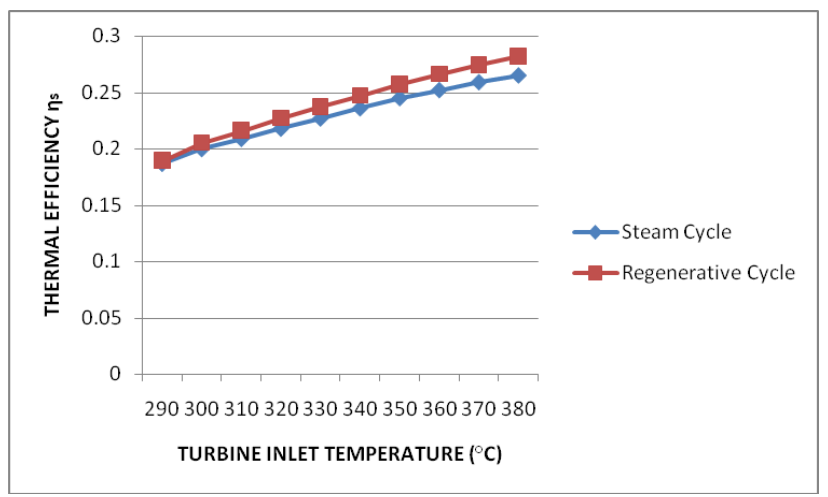

figure 6: Thermal efficiency vs TIT 
This Fig 6 shows the variation of the thermal efficiency with turbine inlet temperature. In steam cycle, the thermal efficiency increases gradually with increase in turbine inlet steam temperature which thereby increases the quality of steam at the turbine exhaust. In regenerative cycle, the thermal efficiency of the cycle increases with the increase in turbine inlet temperature and is higher than the simple steam cycle as the feed water passing through the boiler is hotter and preheated by the heater. In this way heat addition to the boiler is increased and reduces the wetness of steam thereby increasing the efficiency of the cycle. Also at $290^{\circ} \mathrm{C}$, thermal efficiency of both the cycles are nearly same as the steam entering the turbine is not enough preheated to give a better result.

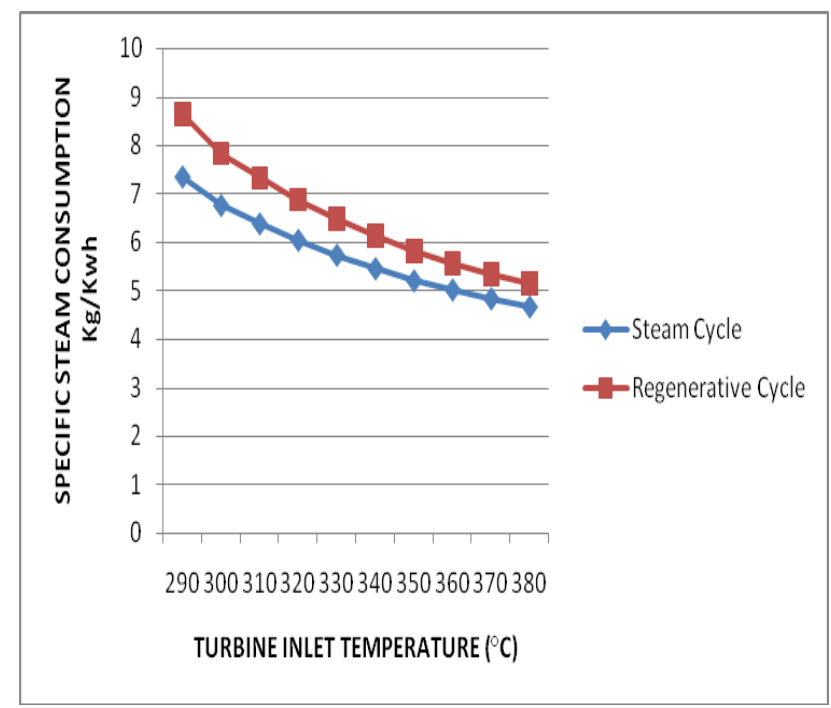

figure 7: SSC vs TIT

This fig 7 shows the variation of specific steam consumption with turbine inlet temperature. Raising the inlet steam temperature also reduces the wetness of the steam in the later stages of the turbine and decreases specific steam consumption. At lower temperature, enthalpy will be low, work done by the turbine will be low, turbine efficiency will be low, hence steam consumption for the required output will be higher. In other words, at higher steam inlet temperature, heat extraction by the turbine will be higher and hence for the required output, steam consumption will reduce. However, the specific steam consumption of regenerative cycle is higher than simple steam cycle as some of the steam is bled from the turbine and brought back through the heater and fed to the boiler through pump. In doing so some work is lost in the turbine but feedwater supplied to boiler is hotter which helps in improving heat addition to the boiler and increases the specific steam consumption.

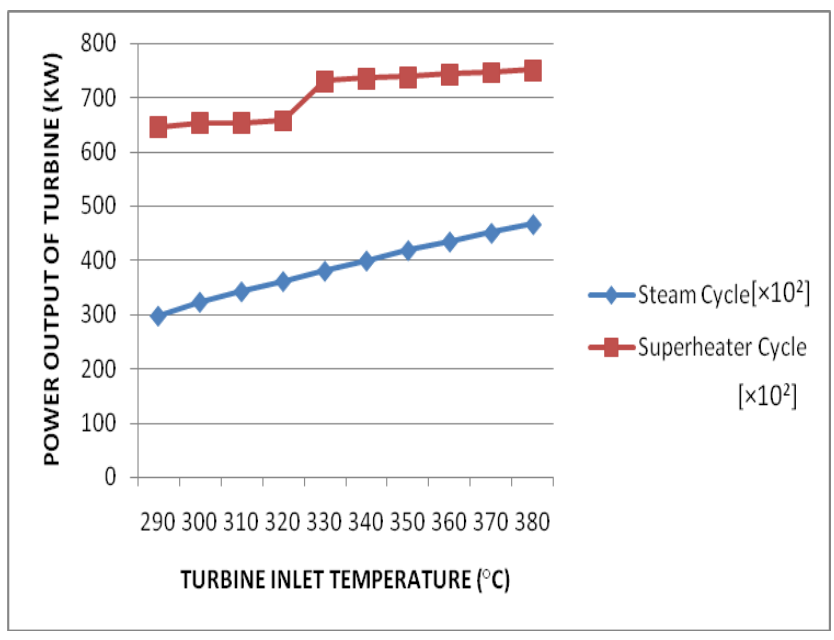

figure 8: Power output vs TIT

This Fig 8 shows the variation of the power output of the turbine with turbine inlet temperature. The increase in turbine inlet temperature means an increase in superheat at constant inlet steam pressure and condenser pressure gives a steady improvement in the power output of the turbine. Raising the inlet steam 
temperature also reduces the wetness of the steam in the later stages of the turbine and improves the power output of the turbine. In steam cycle, the power output of the turbine increases uniformly with increase in turbine inlet steam temperature which thereby increases the quality of steam at the turbine exhaust. A superheater is a device used to convert saturated steam or wet steam into dry steam used for power generation or processes. Superheated steam is steam at a temperature higher than water's boiling point. If saturated steam is heated at constant pressure, its temperature will also remain constant as the steam quality increases towards $100 \%$ dry saturated steam. Continued heat input will then generate superheated steam. Moreover, with increase in superheat at constant pressure increases the mean temperature of heat addition and also the cycle efficiency. As a result of which the quality of steam at turbine exhaust increases and performance of the turbine improves. Therefore, in superheater cycle power output of the turbine increases with the increase in turbine inlet temperature.

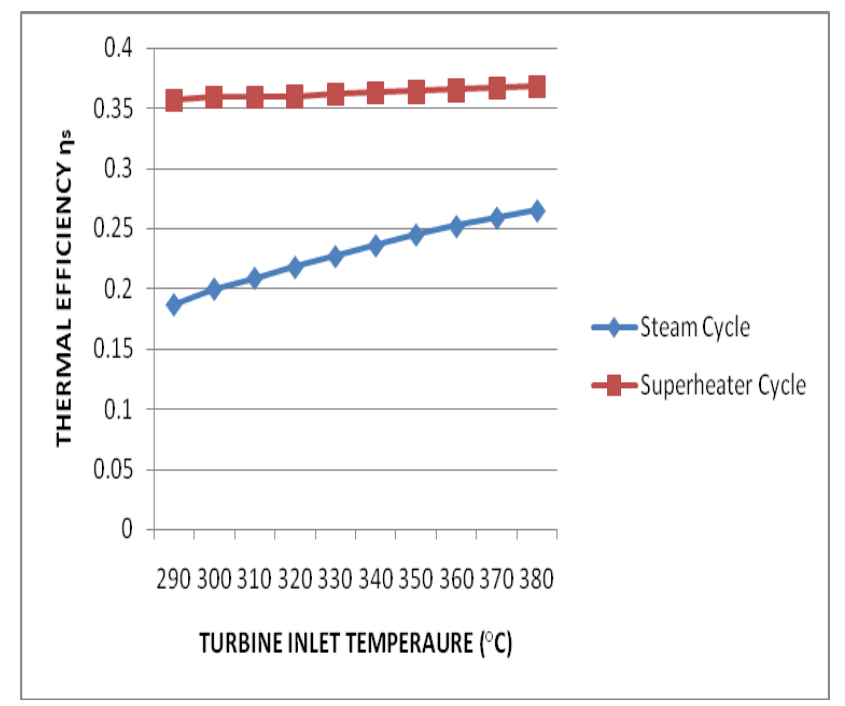

figure 9: Thermal efficiency vs TIT

This Fig 9 shows the variation of the thermal efficiency with turbine inlet temperature. The increase in turbine inlet temperature means an increase in superheat at constant inlet steam pressure and condenser pressure gives a steady improvement in the thermal efficiency of the cycle. Raising the inlet steam temperature also reduces the wetness of the steam in the later stages of the turbine and improves the turbine internal efficiency. In steam cycle, the thermal efficiency increases gradually with increase in turbine inlet steam temperature which thereby increases the quality of steam at the turbine exhaust. A superheater is a device used to convert saturated steam or wet steam into dry steam used for power generation or processes. As a result of which the quality of steam at turbine exhaust increases and performance of the turbine improves. Therfore, in superheater cycle the thermal efficiency almost remains same with the increase in turbine inlet temperature.

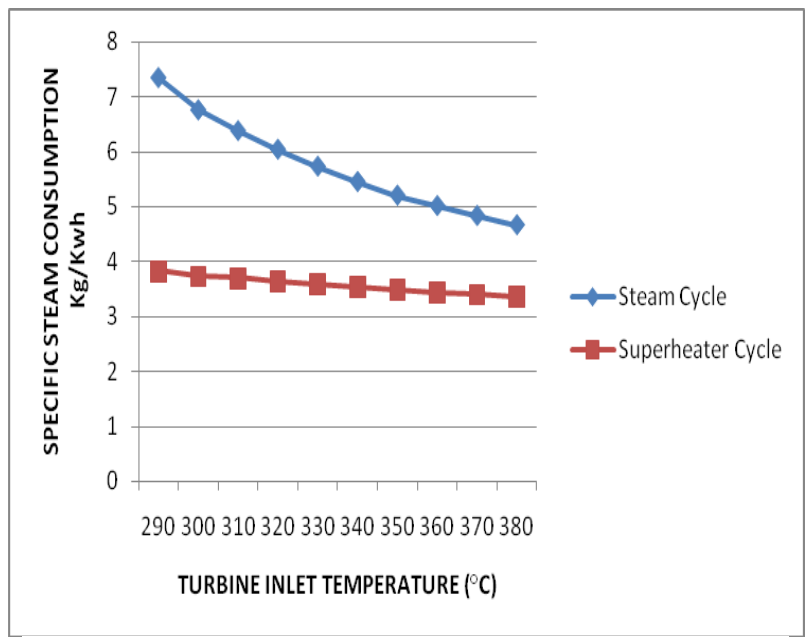

figure 10: SSC vs TIT 
This Fig 10 shows the variation of the specific steam consumption with turbine inlet temperature. At lower temperature, enthalpy will be low, work done by the turbine will be low, turbine efficiency will be low, hence steam consumption for the required output will be higher. In other words, at higher steam inlet temperature, heat extraction by the turbine will be higher and hence for the required output, steam consumption will reduce. However, the specific steam consumption of superheater cycle is lower than simple steam cycle as the quantity of steam may be reduced by $10 \%$ to $15 \%$ for first $38^{\circ} \mathrm{C}$ of superheat and some what less for the next $38^{\circ} \mathrm{C}$ of superheat since additional heat has to be added in the boiler and consequently the capacity to do work in superheated steam is increased thereby reducing the quantity of steam required for a given output of power.

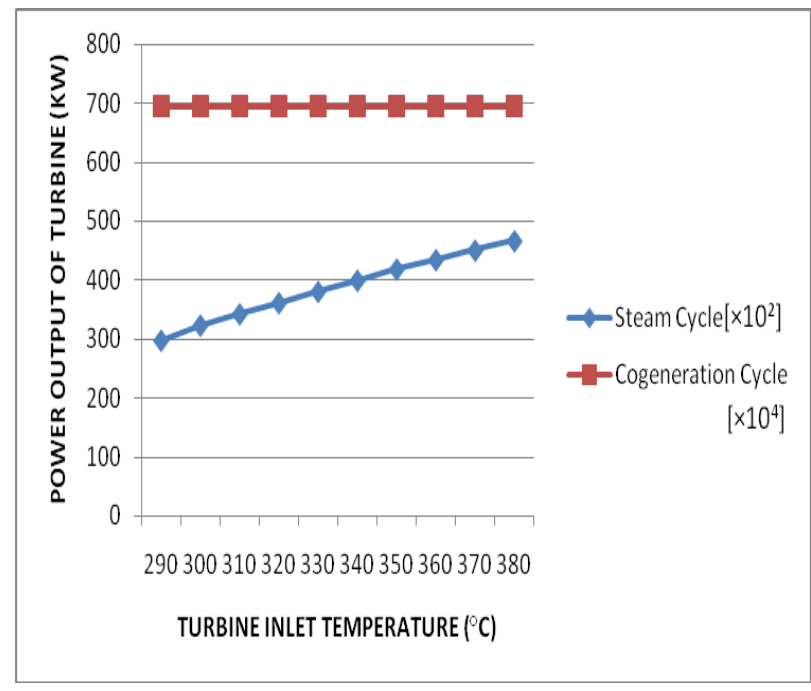

figure 11: Power output vs TIT

This Fig 11 shows the variation of the power output of the turbine with turbine inlet temperature. In steam cycle, the power output of the turbine increases uniformly with increase in turbine inlet steam temperature which thereby increases the quality of steam at the turbine exhaust. In cogeneration cycle, the power output of the turbine is much higher than simple steam cycle as in extraction cum condensing steam turbine as high pressure steam enters the turbine and passes out from the turbine chamber in stages. Mostly the quantity of steam pass out to meet the process needs for process heating and balance quantity of steam condenses in the surface condenser. The energy difference is used for generating power for which the power output of the turbine remains almost constant.

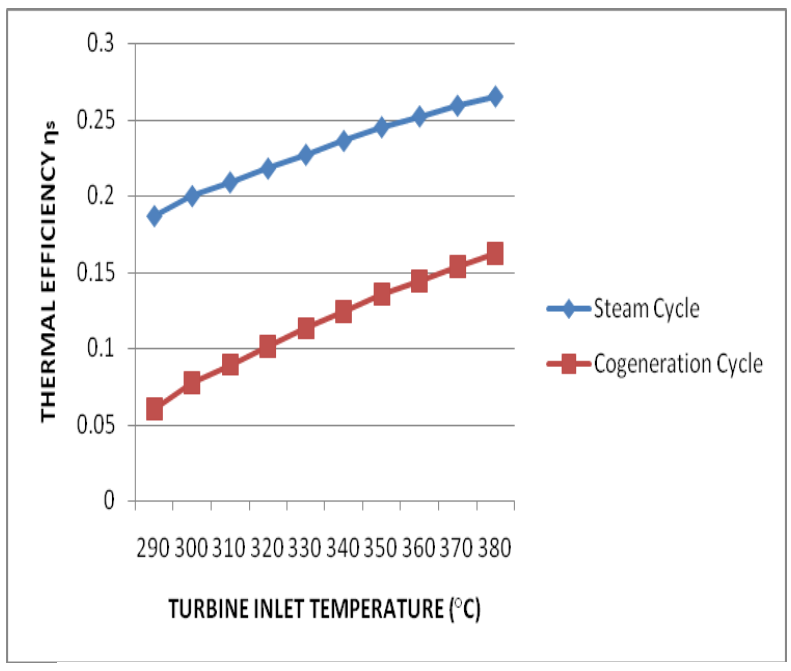

figure 12: Thermal efficiency vs TIT

This Fig 12 shows the variation of the thermal efficiency with turbine inlet temperature. In steam cycle, the thermal efficiency increases gradually with increase in turbine inlet steam temperature which thereby increases the quality of steam at the turbine exhaust. In cogeneration cycle, the thermal efficiency increases gradually with increase in turbine inlet temperature but is lower than simple steam cycle as in extraction cum 
condensing steam turbine as high pressure steam enters the turbine and passes out from the turbine chamber in stages. Mostly the quantity of steam pass out to meet the process needs for process heating and balance quantity of steam condenses in the surface condenser. The energy difference is used for generating power from the low grade waste heat from the process heater at low efficiency. Cogeneration facilities typically operate at pressures significantly below that of $100 \%$ condensing power plants because of possible contamination of returned condensate from process steam and because much condensate is not recovered, meaning having to treat more make-up water.

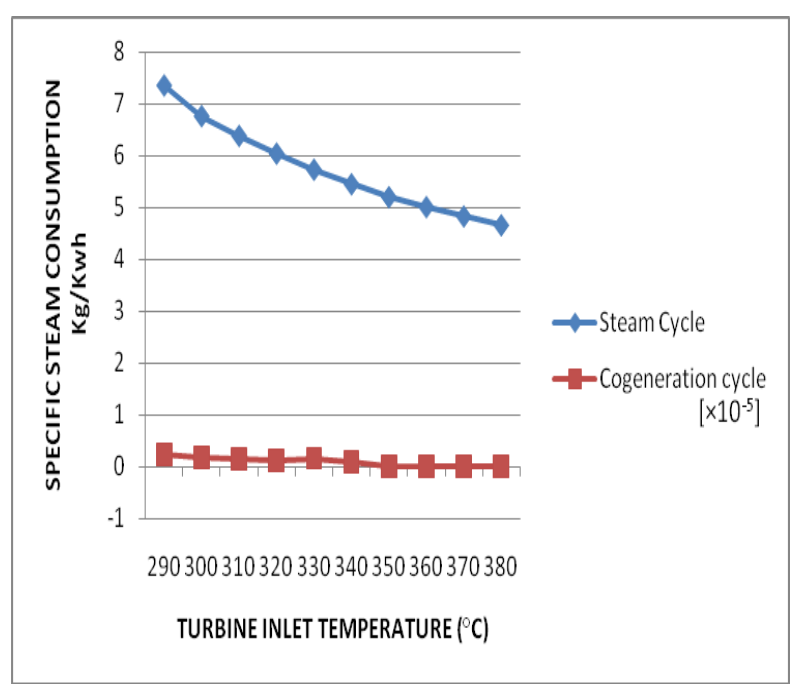

figure 13: SSC vs TIT

This Fig 13 shows the variation of the specific steam consumption with turbine inlet temperature. Raising the inlet steam temperature also reduces the wetness of the steam in the later stages of the turbine and decreases specific steam consumption. At lower temperature, enthalpy will be low, work done by the turbine will be low, turbine efficiency will be low, hence steam consumption for the required output will be higher. In other words, at higher steam inlet temperature, heat extraction by the turbine will be higher and hence for the required output, steam consumption will reduce. However the specific steam consumption of cogeneration cycle is much lower than simple steam cycle because most of the quantity of steam pass out to meet the process needs for process heating and balance quantity of steam condenses in the surface condenser. The energy difference is used for generating power or electricity. Thus the steam extracted from the turbine is used for both heat and power. So the specific steam consumption is much lower.

\section{Conclusion}

It can be stated that the consideration in determining the performance of a steam turbine power plant was evaluated. Parametric study showed that turbine inlet temperature played a very vital role on the performance of a steam turbine power plant in terms of power output of the turbine, thermal efficiency and specific steam consumption. Thus, it can be summarized into the following points:-

- The power output of the turbine was highest in the cogeneration steam plant as compared to the regenerative steam plant and superheater steam plant with the increase in turbine inlet temperature.

- The thermal efficiency of superheater steam plant is highest as compared to the regenerative steam plant and cogeneration steam plant with the increase in turbine inlet temperature.

- The specific steam consumption is least in cogeneration steam plant as compared to the regenerative steam plant and superheater steam plant with the increase in turbine inlet temperature.

Thus the study showed that cogeneration steam power plants are more efficient as compared to conventional steam power plants as it preserves the quality of environment while enhancing the profitability, productivity or usefulness of energy input. The turbine efficiency improves and the specific steam consumption is low. The low grade waste heat from the process heater is used for doing work and also generates power and electricity. 


\section{Acknowledgement}

The authors are thankful to the Almighty for showering blessings in completing this research work. The authors are very much debted for the cooperation and support of Er James Peter, HOD, Mechanical Engineering, SHIATS, Allahabad, India. The authors are also grateful to Prof(Dr) Mohd. Imtiyaz, Dean, SSET, SHIATS for his constant motivation and encouragement for this work.

\section{References}

[1] R.K.Rajput, A Textbook of Power Plant Engineering (Laxmi Publications Pvt. Ltd)

[2] P.K.Nag, Engineering Thermodynamics, (Tata McGraw Hill, New Delhi)

[3] Dr R.Yadav, Fundamentals of Power Plant Engineering,Conventional and Non-Conventional, (Central Publishing House publication, 2011)

[4] Dr R.Yadav, Steam \& Gas Turbines and Power Plant Engineering, (7th Revised edition, Central Publishing House publication, 2009)

[5] Dr P.C.Sharma, Power Plant Engineering, (S.K.Kataria \& Sons Publication, 2010)

[6] R.K. Naradasu, R.K. Konijeti, and V.R. Alluru, thermodynamic analysis of heat recovery steam generator in combined cycle power plant, (Thermal Science, vol. 11, no. 4, pp. 143-156, 2007)

[7] Frutschi, H.U, Highest efficiencies for electrical power generation with combined-cycle plants, (ABB Review, No. 3, pp.12-18, 1999)

[8] Akafuah, K. N., Computer Simulation of the Takoradi Thermal Power Plant, (BSc Project Report, KNUST School of Engineering, Kumasi, pp. 1-5, 1998)

[9] R.K.Kapooria, S.Kumar, K.S.Kasana, An analysis of a thermal power plant working on a Rankine cycle: A theoretical investigation, (Journal of Energy in Southern Africa, Vol 19 No 1,February 2008)

[10] Charles Mborah, Abeekuh Brew Hammond, Seth P. Agbomadzi, Thermodynamic Analysis of the Gas and Steam Turbines at Takoradi Thermal Power Station, (European Journal of Technology and Advanced Engineering Research, ISSN: 1433-2248 No.1 (2010), pp.62-72)

[11] Jinsong Tao, Huanbin Liu, Jigeng Li, Yongjun Yin, Yanming Zhou and Jingjia Jia, Optimization Analysis of Multiple Steam Turbines and Condensers in Paper Mill Power Plant, (International Conference on Renewable Energies and Power Quality (ICREPQ'10) Granada (Spain), 23th to 25th March, 2010)

[12] Juergen Birnbaum, Markus Joecker, Kilian Link, Robert Pitz-Paal, Franziska Tonia, Gerta Zimmer, Simulation of the dynamic behaviour of steam turbines with Modelica, (7th Modelica Conference, Como, Italy, Sep. 20-22, 2009). 